\title{
Herbivory of an invasive slug in a model grassland community can be affected by earthworms and mycorrhizal fungi
}

\author{
Raphaël Trouvé • Thomas Drapela • Thomas Frank • \\ Franz Hadacek • Johann G. Zaller
}

Received: 7 April 2013 /Revised: 17 May 2013 / Accepted: 30 May 2013 / Published online: 18 June 2013

(C) The Author(s) 2013. This article is published with open access at Springerlink.com

\begin{abstract}
Invasion of non-native species is among the top threats for the biodiversity and functioning of native and agricultural ecosystems worldwide. We investigated whether the herbivory of the slug Arion vulgaris (formerly Arion lusitanicus; Gastropoda), that is listed among the 100 worst alien species in Europe, is affected by soil organisms commonly present in terrestrial ecosystems (i.e. earthworms - Annelida: Lumbricidae and arbuscular mycorrhizal fungi-AMF, Glomerales). We hypothesized that slug herbivory would be affected by soil organisms via altered plant nutrient availability and plant quality. In a greenhouse experiment, we created a simple plant community consisting of a grass, a forb, and a legume species and inoculated these systems with either two earthworm species and/or four AMF taxa. Slugs were introduced after plants were established. Earthworms significantly reduced total slug herbivory in AMFinoculated plant communities $(P=0.013)$. Across plant species, earthworms increased leaf total $\mathrm{N}$ and secondary metabolites, AMF decreased leaf thickness. Mycorrhizae induced a shift in slug feeding preference from non-legumes to legumes; the grass was generally avoided by slugs. AMF effects on legume
\end{abstract}

Raphaël Trouvé and Johann G. Zaller contributed equally to this work.

R. Trouvé · T. Drapela · T. Frank · J. G. Zaller $(\bowtie)$

Institute of Zoology, University of Natural Resources and Life

Sciences Vienna, Gregor Mendel Straße 33, 1180 Vienna, Austria

e-mail: johann.zaller@boku.ac.at

F. Hadacek

Albrecht-von-Haller Institute, Plant Biochemistry,

Georg-August-University of Göttingen, Justus-von-Liebig

Weg 11, 370077 Göttingen, Germany

R. Trouvé

Agro Paris Tech, Paris Institute of Technology for Life, Food and Environmental Sciences, 14 rue Girardet, CS 14216, 54042 Nancy, France

T. Drapela

Research Institute of Organic Agriculture (FiBL Austria),

Seidengasse 33-35/13, 1070 Vienna, Austria herbivory can partly be explained by the AMF-induced increase in total $\mathrm{N}$ and decrease in $\mathrm{C} / \mathrm{N}$ ratio; earthworm effects are less clear as no worm-induced alterations of legume plant chemistry were observed. The presence of earthworms increased average AMF colonization of plant roots by $140 \%(P<0.001)$. Total shoot mass was significantly increased by AMF $(P<0.001)$. These data suggest that the feeding behavior of this invasive slug is altered by a belowground control of plant chemical quality and community structure.

Keywords Aboveground-belowground interactions . Gastropods · Invasive species · Lumbricidae · Neobiota · Plant-soil interactions $\cdot$ Soil ecology $\cdot$ Symbiotic fungi

\section{Introduction}

In many terrestrial ecosystems, both arbuscular mycorrhizal fungi (AMF; Glomerales) and earthworms (Oligochaeta: Clitellata) are considered as ecosystem engineers because of their eminent impact on ecosystem structure and functioning (Jones et al. 1997; Cameron 2010). Another factor of increasing importance that affects ecosystem biodiversity, sustainability, and overall functioning is the invasion of non-native species (United Nations Environment Programme 2006). Nevertheless, to the best of our knowledge, the combined impacts of these ubiquitous soil organisms on the activity of invasive herbivores have never been investigated explicitly.

In temperate grasslands in Europe, earthworms represent the dominant fraction of soil animal biomass (Lee 1985; Curry 1994). These earthworm communities commonly consist of only a few species (Edwards and Bohlen 1996) comprising three functional groups: vertically burrowing anecics, horizontally burrowing endogeics, and surface-dwelling epigeics (Bouché 1977). By their activity, earthworms turn over several tons of soil per hectare a year (Zaller and Arnone 1997) and speed up the decomposition and mineralization of organic 
matter in soils (James 1991; Chevallier et al. 2006) with consequences on the growth, nutrient uptake, and quality of plants (Bradford et al. 2002; Scheu 2003; Eisenhauer et al. 2009). These earthworm-induced changes in plant performance have been shown to affect aboveground sap-sucking herbivores (Wurst and Jones 2003; Wurst et al. 2003, 2004a). Earthworms can also be important invasive species with severe consequences on native ecosystems (Bohlen et al. 2004; Migge-Kleian et al. 2006; Sanchez-de Leon and JohnsonMaynard 2009). However, to the best of our knowledge, so far only one study investigated their role in affecting herbivory of invasive slug species (Zaller et al. 2013a).

Arbuscular mycorrhizal fungi form symbiotic associations with about $80 \%$ of the herbaceous plants in grassland ecosystems (Wang and Qiu 2006). The hyphal network of the symbiont serves as extension of the plant root systems, improving plant water and nutrient supply and plant growth (Smith and Read 2008). Numerous studies have shown that presence and species composition of AMF affects plant growth and foliar chemistry with consequences on aboveground herbivores (reviewed in Koricheva et al. 2009). Again, nothing is known on whether AMF affects herbivory of invasive slug species.

The up to 15-cm-long slug species, Arion vulgaris MoquinTandon (Mollusca, Arionidae; formerly widely known as Arion lusitanicus Mabille) expanded all over Europe during the last five decades (South 1992) and is now listed among the 100 worst alien species in Europe due to its devastating effects on natural and agricultural ecosystems (www.europe-aliens.org). Since 1998, this species has also been observed in the USA and given a top national quarantine significance (Cowie et al. 2009) and is suggested to further expand with climate change (Knop and Reusser 2012). Gastropods exhibit diets of wide diversity, but nevertheless reflect distinct food plant preferences (Dirzo 1980; Frank and Friedli 1999; Zaller et al. 2003). Food selection by slugs is broadly defined by two factors: the presence of inhibiting substances (avoidance hypothesis) and the presence of feeding stimulants (preference hypothesis; South 1992). By selectively grazing certain plant species, molluscs alter the species composition and relative abundances within plant communities (Thompson et al. 1993; Hanley et al. 1995a, 1995b; Buschmann et al. 2005).

The aim of this study was to investigate whether the feeding behavior of this invasive generalist slug species is affected by such important soil organisms as earthworms or AMF. Central questions were: (1) Do the consequences of the activity of soil organisms cascade via plants to herbivores? (2) Is slug herbivory more affected by AM fungi than by earthworms? (3) What sort of interactions, if any, occur between these major soil organismic groups? We hypothesized that both soil organisms will influence plant growth and palatability and thereby influence herbivore feeding habits either by altering their consumption rates or changing feeding preferences (Crawley 1983). It has been documented that earthworms and AMF interact directly as earthworms were shown to selectively feed on fungal mycelia (Bonkowski et al. 2000), disperse AMF spores (Reddell and Spain 1991; Gange 1993; Lee et al. 1996), increase AMF biomass in the soil (Gormsen et al. 2004), and either increase (Ortiz-Ceballos et al. 2007) or do not affect root AMF colonization (Wurst et al. 2004b). By enhancing nutrient availability in soil, earthworms might also decrease the mycorrhizal dependency of plants. So far, interrelationships between AMF and earthworms have only been investigated on aboveground sap-sucking insect herbivores (Wurst et al. 2004b). But to the best of our knowledge, potential effects on a mollusc generalist herbivore have never been addressed, despite their documented importance in shaping plant communities (Peters et al. 2006). Assuming that slugs, like insect herbivores are generally limited more by $\mathrm{N}$ than $\mathrm{P}$ (Mattson 1980), we hypothesized to see stronger effects by earthworms than by AMF provided that the mechanism of interaction between soil organisms and the herbivore is a nutritional one. These hypotheses were explored in a full-factorial greenhouse experiment where one slug species could freely choose its food within a simple plant community (one grass, one non-leguminous, one leguminous forb species) that was inoculated with a mix of earthworms (one anecic, one endogeic species) and/or four AMF taxa.

\section{Materials and methods}

\section{Experimental setup}

We conducted a full-factorial pot experiment in a greenhouse of the University of Natural Resources and Life Sciences Vienna (BOKU), Austria, manipulating the factors earthworms and AMF (each of these factors comprising two levels, see details below). Each treatment combination was replicated six times (pot size $14 \times 14 \mathrm{~cm}$ wide, $30 \mathrm{~cm}$ high; volume 3 1). The growth substrate consisted of arable field soil (Haplic Chernozem, silty loam) from the BOKU Experimental Farm mixed with quartz sand (particle size 1.4-2.2 mm) in a 40:60 v/v ratio $\left(\mathrm{pH}-\mathrm{H}_{2} \mathrm{O}=7.4\right.$, $\mathrm{C}_{\text {org }}=24.2 \mathrm{~g} \mathrm{~kg}^{-1}, \mathrm{~N}_{\text {tot }}=0.89 \mathrm{~g} \mathrm{~kg}^{-1}, \mathrm{P}$ in Ca lactate-acetate $(\mathrm{CAL})=61.1 \mathrm{mg} \mathrm{kg}^{-1}, \mathrm{~K}-\mathrm{CAL}=107.6 \mathrm{mg} \mathrm{kg}^{-1}$ ). This mixture was steam-sterilized for $16 \mathrm{~h}$ at $110{ }^{\circ} \mathrm{C}$ in order to kill active AMF propagules living therein. Quartz sand was added in order to facilitate harvesting of roots from this rather loamy field soil. This type of substrate was successfully used in other experiments comprising the same plant, earthworm and AMF taxa (Heiner et al. 2011; Putz et al. 2011; Zaller et al. 2011a). To prevent earthworms and slugs from escaping, the inside bottoms of the pots were lined with two layers of fleece material and the upper rims of the pots 
extended by $30-\mathrm{cm}$-high transparent plastic barriers smeared with soft soap.

Pots were first filled with 21 of the steam-sterilized substrate mixture and then with 1-1 steam-sterilized substrate amended with $80 \mathrm{~g}$ inoculum containing equal proportions of four different AMF taxa ["+M" treatment; Glomus claroideum N.C. Schenck \& G.S. Smith BEG 96, Glomus geosporum (Nicol. \& Gerd.) C. Walker (La Banque Européenne des Glomales e BEG 199), Glomus intraradices N.C. Schenck \& G.S. Smith BEG 163, Glomus mosseae (T.H. Nicolson \& Gerdemann) Gerdemann \& Trappe BEG 198] obtained from a commercial supplier (Symbiom, Lanskroun, Czech Republic; www.symbiom.cz). The AMF control ("M"-M" treatment) was prepared with the same amount of steam-sterilized AMF inoculum.

In April 2010, the grass Arrhenaterum elatius L. J. Presl \& C. Presl, the non-leguminous forb Plantago lanceolata L. and the leguminous forb Trifolium pratense L. were sown directly in the pots using a regular grid of three individuals per species (distance between plants $4 \mathrm{~cm}$ ); plant species always had the same neighboring species. Initially, we sowed two seeds per position and later removed emerging surpassing smaller seedlings. Seed material was obtained from a commercial supplier (Rieger-Hofmann, Blaufelden, Germany). Pots were irrigated daily with a constant volume of tap water. Mesocosms were subjected to natural light cycle; average air temperature during the course of the experiment was $25.2 \pm 1.2{ }^{\circ} \mathrm{C}$ at $35.4 \pm 3.4 \%$ relative humidity. The pots were watered daily with a constant amount of tap water for all treatments.

Earthworms were introduced to the respective pots 28days after plant seeding; by then all plant species were established. The earthworm treatment ("+E") consisted of one individual of the anecic Lumbricus terrestris L. (fresh mass: $3.87 \pm 0.20 \mathrm{~g} \mathrm{pot}^{-1}$, mean $\pm \mathrm{SE}$ ) and two individuals of the endogeic Aporrectodea caliginosa Savigny complex (total fresh mass: $\left.1.66 \pm 0.06 \mathrm{~g} \mathrm{pot}^{-1}\right)$. L. terrestris were purchased from a fishing shop in Vienna, A. caliginosa was collected in the botanical garden of BOKU (Christian and Zicsi 1999). In order to avoid that earthworms act as vectors for mycorrhiza into the treatment pots, they were thoroughly washed and placed in a box containing sterilized soil for 2 days. This procedure was repeated once more; afterwards, earthworms were carefully washed free of attached soil, weighed and introduced into the respective treatment pots.

On day 65 after seeding, two juvenile specimens of the slug A. vulgaris (average length, $4 \mathrm{~cm}$; fresh mass, $2.93 \pm 0.12 \mathrm{~g} \mathrm{pot}^{-1}$ ) were randomly placed on the soil surface of the respective pots. Slugs were collected in a garden near the city of Wiener Neustadt, Austria. Prior to their introduction into the pots they were kept in plastic boxes in a climate chamber $\left(15^{\circ} \mathrm{C}\right)$ and fed with fresh lettuce ad libitum for 5 days; feeding stopped $24 \mathrm{~h}$ prior to introduction to the pots. Slugs were left in the treatment pots for 5 days where they could freely choose their food plants; thereby, we wanted to avoid that a plant individual was completely removed by slugs and would hence affect the feeding on other plant species. Mesocosms were weekly randomized on the glasshouse bench to avoid a potential bias of microclimatic conditions.

\section{Plant measurements}

Plant germination and growth was monitored on average every 3 days until day 39 after seeding. A plant was considered as germinated when its cotyledons were visible.

Destructive harvest of the pots took place between day 69 and 71 after seeding by first removing all slugs from the pots and counting and weighing them. Afterwards, each plant was cut at the soil surface. Maximum leaf length was measured for each of the three species, total number of leaves was counted for P. lanceolata and T. pratense, total number of stems was counted for A. elatius. Afterwards, one individual per plant species and pot was weighed and immediately frozen at $-20{ }^{\circ} \mathrm{C}$ before analyzing the secondary metabolites therein (see below). Another individual per species was used to determine specific leaf area and leaf thickness (see below). The remaining plant material was oven dried at $50{ }^{\circ} \mathrm{C}$ for $48 \mathrm{~h}$ and weighed.

Pots were then flipped over, the soil carefully inspected for earthworms and roots therein sorted out for $7 \mathrm{~min}$ per pot. Roots were carefully washed free of soil over a $1-\mathrm{mm}$ sieve under a jet of tap water. About half of the roots were stored in $50 \%$ ethanol before analyzing AMF colonization, the other portion was dried at $55^{\circ} \mathrm{C}$ for $48 \mathrm{~h}$ to determine dry mass. The percentage of root length colonized by AMF was assessed after ink-staining (Vierheilig et al. 1998) using the grid-line intersect method considering at least 100 intersections per sample under the microscope (Giovanetti and Mosse 1980).

Measuring plant quality and slug damage

Secondary metabolites were assessed on frozen samples after grinding the plant material in liquid nitrogen using pestle and mortar. One hundred milligrams of ground plant material was extracted with $2 \mathrm{ml}$ of a solvent (methanol/acetic acid, 99:1, v/v) over night. Afterwards, the solute was evaporated with a Savant speed vac. Dry samples were re-dissolved with $75 \mu l$ of methanol and analyzed by high-performance liquid chromatography (HPLC). The system was a Dionex Summit equipped with a photodiode array detector and a Famos autosampler. The column was a Phenomenex Synergi Max $\mathrm{C} 12,150 \times 2 \mathrm{~mm}, 5-\mu \mathrm{m}$ particle size. The column oven was adjusted to $40{ }^{\circ} \mathrm{C}$, and the flow rate was $0.2 \mathrm{ml} \mathrm{min}^{-1}$. Solvent A was water/methanol/o-phosphoricacid (9:1:0.5, $v / v / v)$, solvent B was pure methanol. The gradient started with $100 \%$ of $\mathrm{A}$ for $2 \mathrm{~min}$ and then linearly changed to 
$100 \%$ of B within $98 \mathrm{~min}$. The final concentration was held further for $10 \mathrm{~min}$. Five microliters of sample solution were injected. UV spectra were recorded from 590 to $220 \mathrm{~nm}$. The identification of iridoids and flavonoids was based on comparisons of UV spectra, retention times, and elution sequences with an in-house spectrum library that contained reference spectra of isolated and structure elucidated as well as commercially obtained secondary metabolites. As each species showed a specific composition of secondary metabolites, we included different secondary metabolites for each species in the evaluation: for A. elatius we considered flavonoids (apigenin derivates), ferulic acid and a group of unknown phenols; for T. pratense daidzein, glycitein, and genistein as well as five unidentified isoflavones; for $P$. lanceolata the iridoid glucosides catalpol and aucubin. These groups of secondary metabolites were consistently detected in the samples; other metabolites with only occasional appearances were not considered in the statistical analyses. The area of each peak was integrated to facilitate a comparison of secondary metabolite production within an investigated factor but not between plant species.

Oven-dried shoot samples were ground using a ball mill (Mixer Mill MM 200, Retsch, Haan, Germany) and analyzed for total carbon $\left(\mathrm{C}_{\mathrm{tot}}\right)$ and nitrogen $\left(\mathrm{N}_{\mathrm{tot}}\right)$ concentration using an elementary analyzer (LECO-CN2000, LECO Corp., Saint Joseph, MI, USA).

Specific leaf area (SLA, square centimeter per gram) was calculated after scanning the biggest leaf of each plant species per pot using a flatbed scanner (300 DPI) and measuring the leaf area with an image analysis software (Scion Image, www.scioncorp.com) and dividing this area by the respective dry mass after drying at $55^{\circ} \mathrm{C}$ for $24 \mathrm{~h}$.

Slug herbivory was assessed during the harvest by carefully inspecting all leaves for damage and estimating the leaf area eaten by slugs using millimeter paper. By using the specific SLA ratio per leaf, we were able to convert the eaten area into consumed biomass.

\section{Statistical analyses}

Homogeneity of variances was tested using the Levene's test; normality of residuals was checked using qq-plots. Data were $\log$ transformed when they were not fulfilling the assumptions of analysis of variance (ANOVA). Threeway ANCOVAs with AMF, earthworms and plant species as factors were used to compare individual variables among treatments. Tukey's HSD tests were used for pairwise multiple comparisons between treatments. We used the individual age of a plant (i.e., number of days past germination or emergence), initial slug mass pot ${ }^{-1}$ and initial earthworm mass $\operatorname{pot}^{-1}$ as covariables in the analyses. Root mass did not meet ANOVA assumptions even after transformation and was therefore analyzed using the non-parametric Kruskal-
Wallis test. All statistical analyses were performed using the software package R.2.10.1 (R Development Core Team 2008, www.Rproject.org). Values given in the text are arithmetic means \pm 1 standard error. Effects $0.05>P<0.10$ were considered as marginally significant.

\section{Results}

Mycorrhization of plant roots was significantly higher when earthworms were present $(14.3 \pm 2.7$ vs. $34.5 \pm 2.9 \%$ for $-\mathrm{E}$ vs. + E treatments, respectively; $\mathrm{F}=25.672, P<0.001$; generally, no mycorrhization was detected in $-\mathrm{M}$ pots). At harvest of the pots we found $0.86 \pm 0.18 \mathrm{~g} \mathrm{pot}^{-1}$ earthworms in $-\mathrm{M}$ and $0.83 \pm 0.10 \mathrm{~g} \mathrm{pot}^{-1}$ earthworm fresh mass in $+\mathrm{M}$ pots; AMF had no impact on earthworm fresh mass recovery $(t$ test: $P=0.880$ ). At harvest, we found all slug individuals introduced; slug fresh mass at the end of the experiment was $2.64 \pm 0.19 \mathrm{~g} \mathrm{pot}^{-1}$, which is $93 \%$ of the initial fresh mass ( $t$ test: $P=0.634)$. Neither earthworms nor AMF affected slug fresh mass. Seed germination differed between species: $50 \%$ seed germination was reached for $T$. pratense after 7 days, for A. elatius after 9 days, and for $P$. lanceolata after 11 days. Twenty-five days after seeding, the maximum germination was reached for all species: $100 \%$ for T. pratense, $98 \%$ for $P$. lanceolata, and $85 \%$ for $A$. elatius. The presence of AMF had no impact on the time of germination or on the number of germinating seeds (data not shown).

Of the individual plant species, shoot mass of $T$. pratense was significantly higher $(P<0.001)$ and $P$. lanceolata marginally significantly higher $(P=0.051)$ in $+\mathrm{M}$ pots than $-\mathrm{M}$ pots (Fig. 1a, Table 1). Earthworms had no effect on shoot mass of individual plant species; however, there was a significant interaction between AMF and earthworms on $T$. pratense shoot mass $(P=0.011)$ with similar shoot mass at $+\mathrm{M}$ but a decrease in shoot mass at $-\mathrm{M}$ (Fig. 1a, Table 1). Total shoot mass was significantly affected by both earthworm and AMF (Fig. 1b, Table 1). Root dry mass per pot was $1.358 \pm 0.150 \mathrm{~g}$ and unaffected by AMF or earthworms (Table 1). All T. pratense roots showed root nodules; however, these were not quantified.

Plant species differed significantly in their leaf $\mathrm{C}_{\text {tot }}, \mathrm{N}_{\text {tot }}$, $\mathrm{C} / \mathrm{N}$ ratio, total secondary metabolites, and specific leaf area (Table 2, Table 3); across plant species earthworms significantly affected $\mathrm{N}_{\text {tot }}$ and total secondary metabolites and marginally significantly $\mathrm{C} / \mathrm{N}$ ratios, AMF only tended to affect specific leaf area (Table 2, Table 3). Regarding leaf quality variables, several significant interactions between earthworms and AMF were detected (Table 3). Earthworms significantly affected $\mathrm{C}_{\text {tot }}$ and specific leaf area of $A$. elatius and total secondary metabolites of $P$. lanceolata but did not affect leaf quality of $T$. pratense (Table 3 ). AMF significantly affected total secondary metabolites of $P$. lanceolata 
Fig. 1 Species-specific (a) and total (b) shoot mass production in response to earthworms $(-E$, no earthworms; $+E$, earthworms added) or AM fungi ( $-M$, no AMF inoculation; $+M$, with AMF inoculation). Different letters above bars denote significant differences (Tukey's HSD test, $P<0.05)$. Means \pm SE, $n=6$
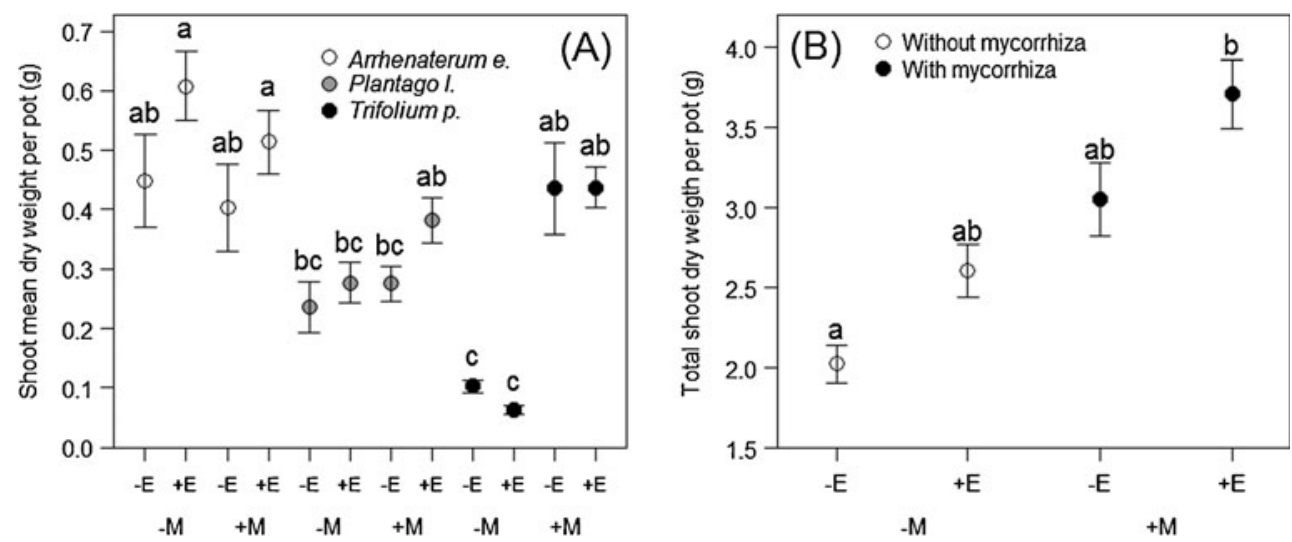

$(P<0.001)$ and $\mathrm{N}_{\text {tot }}(P<0.001) \mathrm{C} / \mathrm{N}$ ratio $(P<0.001)$ and specific leaf area $(P=0.045)$ of $T$. pratense (Table 3$)$.

Slugs were observed climbing on all three plant species. Of individual plant species only herbivory on $T$. pratense was significantly affected by AMF $(P<0.001)$ or earthworms $(P=0.001$; Fig. 2a, Table 4$)$. Total plant mass consumed by slugs was significantly affected by $\operatorname{AMF}(P=0.007)$ and earthworms $(P=0.013$; Fig. 2 b, Table 4$)$. Leaf consumption by slugs differed significantly between plant species $(P<0.001)$; this was influenced by AMF or earthworms (significant interaction terms; Table 4).

In the slug's diet, relative consumption of $P$. lanceolata was $42 \%$ reduced by $\mathrm{AMF}$ and remained unaffected by earthworms; relative consumption of $T$. pratense was $342 \%$ increased by $\mathrm{AMF}(P<0.001)$ and significantly reduced by earthworms $(P<0.001$; Fig. 3; Table 4$)$.

\section{Discussion}

This study demonstrates that the feeding behavior of an aggressive slug in many agroecosystems can be affected by interactions between earthworms and AMF. The documented influence of earthworms and/or AMF on the food selection of these generalist slugs suggests potential far-reaching consequences on the structure, plant diversity and functioning of grassland communities (South 1992; Frank 2003; Peters et al. 2006), which definitely merit further attention.

From previous studies on effects of earthworms or AMF in isolation, we already know that plant growth, plant development, and insect herbivores can be affected by either AMF or earthworms (Scheu 2003; Smith and Read 2008). Total root biomass was surprisingly unaffected by the activity of both soil organisms suggesting a rather slow response of
Table 1 ANCOVA table for the effects of arbuscular mycorrhizal fungi (AMF) and earthworms on plant productivity (gram of dry mass per pot). Plant age (i.e., number of days after emergence) was used as a covariable in the tests

Significant effects are in bold; only significant interactions are shown

\begin{tabular}{llrrr}
\hline Response variable & Explanatory variable & $D f$ & $F$ value & $P$ value \\
\hline Total shoot mass & Plant age & 1 & $\mathbf{1 1 . 1 5}$ & $\mathbf{0 . 0 0 2}$ \\
& AMF & 1 & $\mathbf{3 6 . 7 2}$ & $<\mathbf{0 . 0 0 1}$ \\
Total root mass & Earthworms & 1 & $\mathbf{7 . 7 2}$ & $\mathbf{0 . 0 1 1}$ \\
& Plant age & 1 & 3.89 & 0.055 \\
Total shoot+root mass & AMF & 1 & 0.01 & 0.984 \\
& Earthworms & 1 & 0.13 & 0.712 \\
& Plant age & 1 & $\mathbf{6 . 9 5}$ & $\mathbf{0 . 0 1 2}$ \\
A. elatius shoot mass & AMF & 1 & $\mathbf{1 6 . 4 9}$ & $<\mathbf{0 . 0 0 1}$ \\
& Earthworms & 1 & $\mathbf{4 . 2 5}$ & $\mathbf{0 . 0 4 5}$ \\
& Age of A. elatius & 1 & $\mathbf{8 . 5 5}$ & $\mathbf{0 . 0 0 5}$ \\
& AMF & 1 & 1.22 & 0.276 \\
T. pratense shoot mass & Earthworms & 1 & 2.21 & 0.144 \\
& Age of P. lanceolata & 1 & $\mathbf{4 . 8 8}$ & $\mathbf{0 . 0 3 2}$ \\
& AMF & 1 & 4.03 & 0.051 \\
& Earthworms & 1 & 0.10 & 0.099 \\
& Age of T. pratense & 1 & $\mathbf{6 1 . 6 1}$ & $<\mathbf{0 . 0 0 1}$ \\
& AMF & 1 & $\mathbf{2 8 1 . 5 9}$ & $<\mathbf{0 . 0 0 1}$ \\
& Earthworms & 1 & 2.86 & 0.098 \\
& AMF $\times$ earthworms & 1 & $\mathbf{7 . 0 6}$ & $\mathbf{0 . 0 1 1}$ \\
\hline & & & &
\end{tabular}


Table 2 Effects of earthworms $(-\mathrm{E}$, no earthworms; +E, with earthworms) and arbuscular mycorrhizal fungi (AMF) on leaf total $\mathrm{C}\left(\mathrm{C}_{\text {tot }} \%\right)$, total $\mathrm{N}\left(\mathrm{N}_{\text {tot. }} \%\right)$, concentrations of total secondary metabolites (TSM, integrated peak areas) and specific leaf area (SLA, square centimeter per gram)

Different letters indicate a significant difference between treatments (Tukey HSD test, $P<0.05$ )

\begin{tabular}{|c|c|c|c|c|}
\hline \multirow[b]{2}{*}{ Variable } & \multicolumn{2}{|l|}{ Without AMF } & \multicolumn{2}{|l|}{ With AMF } \\
\hline & $-\mathrm{E}$ & $+\mathrm{E}$ & $-\mathrm{E}$ & $+\mathrm{E}$ \\
\hline \multicolumn{5}{|c|}{ Across all species } \\
\hline $\mathrm{C}_{\text {tot }}$ & $32.10 \pm 0.18 \mathrm{a}$ & $32.73 \pm 0.21 \mathrm{a}$ & $32.50 \pm 0.21 \mathrm{a}$ & $32.28 \pm 0.2 \mathrm{a}$ \\
\hline $\mathrm{N}_{\text {tot }}$ & $1.58 \pm 0.07 \mathrm{a}$ & $1.54 \pm 0.06 \mathrm{a}$ & $1.51 \pm 0.08 \mathrm{a}$ & $1.77 \pm 0.08 \mathrm{a}$ \\
\hline $\mathrm{C} / \mathrm{N}$ ratio & $21.57 \pm 0.90 \mathrm{a}$ & $22.37 \pm 0.81 \mathrm{a}$ & $23.75 \pm 1.26 \mathrm{a}$ & $20.02 \pm 1.05 \mathrm{a}$ \\
\hline TSM & $1,269 \pm 517 \mathrm{a}$ & $2,383 \pm 486 \mathrm{ab}$ & $2,886 \pm 340 \mathrm{~b}$ & $2,976 \pm 186 b$ \\
\hline SLA & $405.0 \pm 19.3 \mathrm{a}$ & $395.1 \pm 17.8 \mathrm{a}$ & $375.0 \pm 12.8 \mathrm{a}$ & $362.3 \pm 25.4 \mathrm{a}$ \\
\hline \multicolumn{5}{|c|}{ Arrhenatherum elatius } \\
\hline $\mathrm{C}_{\text {tot }}$ & $32.49 \pm 0.31 \mathrm{a}$ & $33.45 \pm 0.27 \mathrm{a}$ & $32.58 \pm 0.31 \mathrm{a}$ & $32.86 \pm 0.31 \mathrm{a}$ \\
\hline $\mathrm{N}_{\text {tot }}$ & $1.42 \pm 0.10 \mathrm{a}$ & $1.44 \pm 0.08 \mathrm{a}$ & $1.11 \pm 0.06 \mathrm{a}$ & $1.48 \pm 0.12 \mathrm{a}$ \\
\hline $\mathrm{C} / \mathrm{N}$ ratio & $21.07 \pm 1.51 \mathrm{a}$ & $23.91 \pm 1.08 \mathrm{a}$ & $30.03 \pm 1.60 \mathrm{~b}$ & $23.97 \pm 1.92 \mathrm{a}$ \\
\hline TSM & $2,619 \pm 771 \mathrm{a}$ & $3,655 \pm 684 a$ & $1,827 \pm 231 \mathrm{a}$ & $3,429 \pm 1195 \mathrm{a}$ \\
\hline SLA & $484.1 \pm 46.1 \mathrm{a}$ & $416.8 \pm 23.6 \mathrm{a}$ & $507.4 \pm 40.3 \mathrm{a}$ & $373.6 \pm 28.8 \mathrm{a}$ \\
\hline \multicolumn{5}{|c|}{ Plantago lanceolata } \\
\hline $\mathrm{C}_{\text {tot }}$ & $31.35 \pm 0.29 \mathrm{ab}$ & $31.9 \pm 0.33 \mathrm{ab}$ & $32.45 \pm 0.29 \mathrm{a}$ & $31.18 \pm 0.21 b$ \\
\hline $\mathrm{N}_{\text {tot }}$ & $1.48 \pm 0.13 \mathrm{a}$ & $1.36 \pm 0.09 \mathrm{a}$ & $1.29 \pm 0.06 \mathrm{a}$ & $1.61 \pm 0.15 \mathrm{a}$ \\
\hline $\mathrm{C} / \mathrm{N}$ ratio & $22.5 \pm 1.77 \mathrm{a}$ & $24.47 \pm 1.36 \mathrm{a}$ & $25.72 \pm 1.32 \mathrm{a}$ & $21.13 \pm 1.68 \mathrm{a}$ \\
\hline TSM & $1,482 \pm 87 \mathrm{a}$ & $1,935 \pm 114 \mathrm{a}$ & $1,566 \pm 92 \mathrm{a}$ & $1,927 \pm 145 \mathrm{a}$ \\
\hline SLA & $247.6 \pm 3.9 \mathrm{a}$ & $269.2 \pm 17.5 \mathrm{a}$ & $218.0 \pm 7.1 \mathrm{a}$ & $255.8 \pm 21.0 \mathrm{a}$ \\
\hline \multicolumn{5}{|c|}{ Trifolium pratense } \\
\hline $\mathrm{C}_{\text {tot }}$ & $32.32 \pm 0.21 \mathrm{a}$ & $32.91 \pm 0.34 \mathrm{a}$ & $32.46 \pm 0.52 \mathrm{a}$ & $32.89 \pm 0.28 \mathrm{a}$ \\
\hline $\mathrm{N}_{\text {tot }}$ & $1.85 \pm 0.07 \mathrm{a}$ & $1.87 \pm 0.09 \mathrm{a}$ & $2.10 \pm 0.07 \mathrm{~b}$ & $2.21 \pm 0.05 b$ \\
\hline $\mathrm{C} / \mathrm{N}$ ratio & $18.08 \pm 0.88 \mathrm{ab}$ & $18.56 \pm 1.11 \mathrm{a}$ & $15.32 \pm 0.39 b c$ & $14.86 \pm 0.33 \mathrm{c}$ \\
\hline TSM & $3,255 \pm 316 a$ & $2,509 \pm 722 \mathrm{a}$ & $3,291 \pm 348 \mathrm{a}$ & $2,947 \pm 130 \mathrm{a}$ \\
\hline SLA & $483.1 \pm 31.9 \mathrm{a}$ & $500.4 \pm 37.2 \mathrm{a}$ & $400.1 \pm 13.7 \mathrm{a}$ & $458.1 \pm 29.1 \mathrm{a}$ \\
\hline
\end{tabular}

roots to these soil organisms, and that root biomass (e.g., as opposed to root length) represents a too insensitive trait to differentiate between these two soil organisms.

Previous studies investigating combined effects of earthworms and AMF provide some hints of potential underlying mechanisms (Tuffen et al. 2002; Wurst et al. 2004b; Eisenhauer et al. 2009; Milleret et al. 2009; Zarea et al. 2009; Wurst and Forstreuter 2010; Zaller et al. 2011c). However, the lack of a general pattern point to contextspecific interactions where different species of earthworms, AMF and plants and different experimental settings yield different results.

Overall, slugs preferred the legume and the forb over the grass although leaf quality variables did not clearly indicate less palatability of the latter. The tendency of molluscs to avoid grasses has been noted previously (Dirzo 1980) and may in the long term contribute to an increased abundance of grasses in such model systems. We expected to see either preference for plants with high nutrient contents and avoidance of less palatable plants or compensatory feeding with more damage on plants with thinner leaves (higher SLA values) because we assumed that slugs need to consume more leaf material to achieve a given nutrient value or avoid inhibiting substances (South 1992; Zaller et al. 2003). However, it seems that all assessed leaf quality variables interact in complex ways especially in a situation where herbivores could freely choose their food sources. The shift in the functional group preference from $P$. lanceolata in $-\mathrm{M}$ treatments to $T$. pratense in $+\mathrm{M}$ treatments is likely due to an increased foliar $\mathrm{N}$ content of the latter species with mycorrhiza. Of the three species, T. pratense had the highest $\mathrm{N}_{\text {tot }}$ and lowest $\mathrm{C} / \mathrm{N}$ ratio across treatments, however was only preferred in $+\mathrm{M}$ treatments. The lack of a relationship between plant quality and slug herbivory has been found previously suggesting that other factors than plant quality are more important (Peters et al. 2000; Zaller et al. 2003; Zaller et al. 2013a). The possibility exists that the greater overall abundance of food may have influenced consumption in this experiment (Arnone et al. 1995), for instance that slugs preferred the least abundant plant species. However, in our experiment slug consumption was not influenced by the quantity of available food (Figs. 2 and 3) which agrees with Cook et al. (1996). Other explanations could be that slugs just sample the available foods, even those which are less palatable, or, that slugs require a varied food intake so that uncommon and often unpalatable foods may be eaten (South 
Table 3 ANOVA table for the effects of plant species (Spp), arbuscular mycorrhizal fungi (AMF) and earthworms (EW) on leaf total $\mathrm{C}\left(\mathrm{C}_{\text {tot }} \%\right)$, total $\mathrm{N}\left(\mathrm{N}_{\text {tot }}\right.$. $\%$ ), concentrations of total secondary metabolites (TSM, integrated peak areas) and specific leaf area (SLA, square centimeter per gram)

\begin{tabular}{|c|c|c|c|c|}
\hline Response variable & Explanatory variable & $D f$ & $F$ value & $P$ value \\
\hline \multicolumn{5}{|l|}{ Across all species } \\
\hline \multirow[t]{5}{*}{ Leaf $C_{\text {tot }}$} & Spp. & 2 & 14.04 & $<0.001$ \\
\hline & AMF & 1 & 0.01 & 0.926 \\
\hline & Earthworms & 1 & 1.75 & 0.188 \\
\hline & Spp. $\times$ EW & 2 & 3.40 & 0.036 \\
\hline & $\mathrm{AMF} \times \mathrm{EW}$ & 1 & 5.58 & 0.020 \\
\hline \multirow[t]{5}{*}{ Leaf $\mathrm{N}_{\text {tot }}$} & Spp. & 1 & 53.61 & $<0.001$ \\
\hline & AMF & 1 & 2.26 & 0.135 \\
\hline & Earthworms & 1 & 4.09 & 0.045 \\
\hline & Spp. $\times$ EW & 2 & 6.82 & 0.002 \\
\hline & $\mathrm{AMF} \times \mathrm{EW}$ & 1 & 6.88 & 0.010 \\
\hline \multirow[t]{5}{*}{ Leaf $\mathrm{C} / \mathrm{N}$ ratio } & Spp. & 2 & 45.91 & $<0.001$ \\
\hline & AMF & 1 & 0.02 & 0.877 \\
\hline & Earthworms & 1 & 3.70 & 0.057 \\
\hline & $\mathrm{Spp} \times \mathrm{AMF}$ & 2 & 5.55 & 0.005 \\
\hline & $\mathrm{AMF} \times \mathrm{EW}$ & 1 & 8.03 & 0.005 \\
\hline \multirow[t]{2}{*}{ TSM } & AMF & 1 & 0.01 & 0.971 \\
\hline & Earthworms & 1 & 6.19 & 0.021 \\
\hline \multirow[t]{4}{*}{ SLA } & Species & 2 & 73.38 & $<0.001$ \\
\hline & AMF & 1 & 3.84 & 0.054 \\
\hline & Earthworms & 1 & 0.48 & 0.492 \\
\hline & $\mathrm{Spp} \times \mathrm{EW}$ & 2 & 7.83 & $<0.001$ \\
\hline \multicolumn{5}{|c|}{ Arrhenatherum elatius } \\
\hline \multirow[t]{2}{*}{ Leaf $C_{\text {tot }}$} & AMF & 1 & 0.52 & 0.474 \\
\hline & Earthworm & 1 & 4.41 & 0.041 \\
\hline \multirow[t]{2}{*}{ Leaf $\mathrm{N}_{\text {tot }}$} & AMF & 1 & 1.69 & 0.200 \\
\hline & Earthworm & 1 & 3.41 & 0.071 \\
\hline \multirow[t]{2}{*}{ Leaf $\mathrm{C} / \mathrm{N}$ ratio } & $\mathrm{AMF}$ & 1 & 3.41 & 0.071 \\
\hline & Earthworm & 1 & 3.67 & 0.062 \\
\hline \multirow[t]{2}{*}{ TSM } & AMF & 1 & 1.50 & 0.288 \\
\hline & Earthworm & 1 & 2.28 & 0.206 \\
\hline \multirow[t]{2}{*}{ SLA } & AMF & 1 & 0.08 & 0.783 \\
\hline & Earthworms & 1 & 7.88 & 0.011 \\
\hline \multicolumn{5}{|l|}{ Plantago lanceolata } \\
\hline \multirow[t]{3}{*}{ Leaf $C_{\text {tot }}$} & AMF & 1 & 0.20 & 0.654 \\
\hline & Earthworm & 1 & 2.02 & 0.162 \\
\hline & $\mathrm{AMF} \times \mathrm{EW}$ & 1 & 10.15 & 0.003 \\
\hline \multirow[t]{2}{*}{ Leaf $\mathrm{N}_{\text {tot }}$} & AMF & 1 & 0.13 & 0.715 \\
\hline & Earthworm & 1 & 0.85 & 0.363 \\
\hline \multirow[t]{3}{*}{ Leaf $\mathrm{C} / \mathrm{N}$ ratio } & AMF & 1 & 0.03 & 0.848 \\
\hline & Earthworm & 1 & 0.91 & 0.345 \\
\hline & $\mathrm{AMF} \times \mathrm{EW}$ & 1 & 4.53 & 0.039 \\
\hline \multirow[t]{3}{*}{ TSM } & $\mathrm{AMF}$ & 1 & 22.57 & $<0.001$ \\
\hline & Earthworm & 1 & 64.19 & 0.001 \\
\hline & $\mathrm{AMF} \times \mathrm{EW}$ & 1 & 23.24 & 0.009 \\
\hline \multirow[t]{2}{*}{ SLA } & AMF & 1 & 2.27 & 0.147 \\
\hline & Earthworms & 1 & 4.34 & 0.051 \\
\hline \multicolumn{5}{|l|}{ Trifolium pratense } \\
\hline \multirow[t]{2}{*}{ Leaf $C_{\text {tot }}$} & AMF & 1 & 0.04 & 0.849 \\
\hline & Earthworm & 1 & 2.24 & 0.143 \\
\hline
\end{tabular}


Table 3 (continued)

\begin{tabular}{lllrr}
\hline Response variable & Explanatory variable & $D f$ & $F$ value & $P$ value \\
\hline Leaf $\mathrm{N}_{\text {tot }}$ & AMF & 1 & 23.15 & $<\mathbf{0 . 0 0 1}$ \\
\multirow{2}{*}{ Leaf C/N ratio } & Earthworm & 1 & 0.40 & 0.531 \\
& AMF & 1 & $\mathbf{1 7 . 7 4}$ & $<\mathbf{0 . 0 0 1}$ \\
TSM & Earthworm & 1 & 0.01 & 0.991 \\
& AMF & 1 & 0.36 & 0.558 \\
SLA & Earthworm & 1 & 0.70 & 0.417 \\
& AMF & 1 & 4.58 & $\mathbf{0 . 0 4 5}$ \\
& Earthworms & 1 & 1.66 & 0.213 \\
\hline
\end{tabular}

1992). Fenner et al. (1999) tested the palatability of 29 plant species for the slug Deroceras reticulatum using food-choice experiments and it was found that $P$. lanceolata is about three times more palatable than $T$. pratense; a pattern that was observed in the current experiment only in treatments without AMF. Assuming that the results from this food-choice experiment with a different slug species can be transferred to our experimental scenario this suggests that AMF may reduce the palatability of $P$. lanceolata as compared to $T$. pratense. The finding that AMF made the legume T. pratense more palatable indicates that AMF improved the nutrient availability, agreeing with numerous studies showing that plant nutritive value was higher in the presence of mycorrhiza (Bennett et al. 2006; Zaller et al. 2011a). Slugs consumed three times more biomass of the legume in presence of AMF; however, this effect was alleviated by the presence of earthworms. Earthworms have recently been found to alleviate insect herbivore damage (Wurst 2010) and quantitatively reduce secondary metabolites of $P$. lanceolata (Wurst et al. 2004b) - the current study confirms this also for slugs. Although slugs fed well on plant material, their fresh mass was slightly lower at the end of the experiment referring to some stress during the course of the experiment.

In our experiment, we saw several interactions between AMF and earthworms suggesting that different effects are induced at different levels. We found significant effects of earthworms and AMF on secondary metabolites of $P$. lanceolata, which is in accordance with previous reports (Wurst et al. 2004a). The former study also found AMF induced reduction in $\mathrm{N}_{\text {tot }}$ and earthworm-induced reductions in catalpol concentrations which was not confirmed by our results (data not shown). Our study suggest that the effects of earthworms and AMF go beyond a simple amelioration of the plants' nutritional status involving other interactions that might influence plant community structure (Hempel et al. 2009; Zaller et al. 2011b).

We observed a decline of earthworm biomass over the course of the experiment irrespective of AMF treatment. Some decline in earthworm biomass is frequently observed in earthworm laboratory studies, especially when experiments lasted several months (e.g., Wurst et al. 2004b; Zaller et al. 2013b). In the current study, we observed regular earthworm activity by surface castings until the end of the experiment; however, we did not quantify this activity and did not count the number of earthworms present at harvest. Therefore, we cannot show whether the biomass loss derives from escaping earthworms or mortality during the course of the experiment. The decline in earthworms could also be due to low bacteria or fungi biomass in soil due to sterilization (Bonkowski et al. 2000) or due to the use of rather small
Fig. 2 Absolute herbivory on A. elatius, P. lanceolata, and $T$. pratense (a) and total slug herbivory $(\mathbf{b})$ in response to earthworms $(-E$, no earthworms; $+E$, earthworms added) or AM fungi ( $-M$, no AMF inoculation; $+M$, with AMF inoculation). Different letters above bars denote significant differences (Tukey's HSD test, $P<0.05)$. Means \pm SE, $n=6$
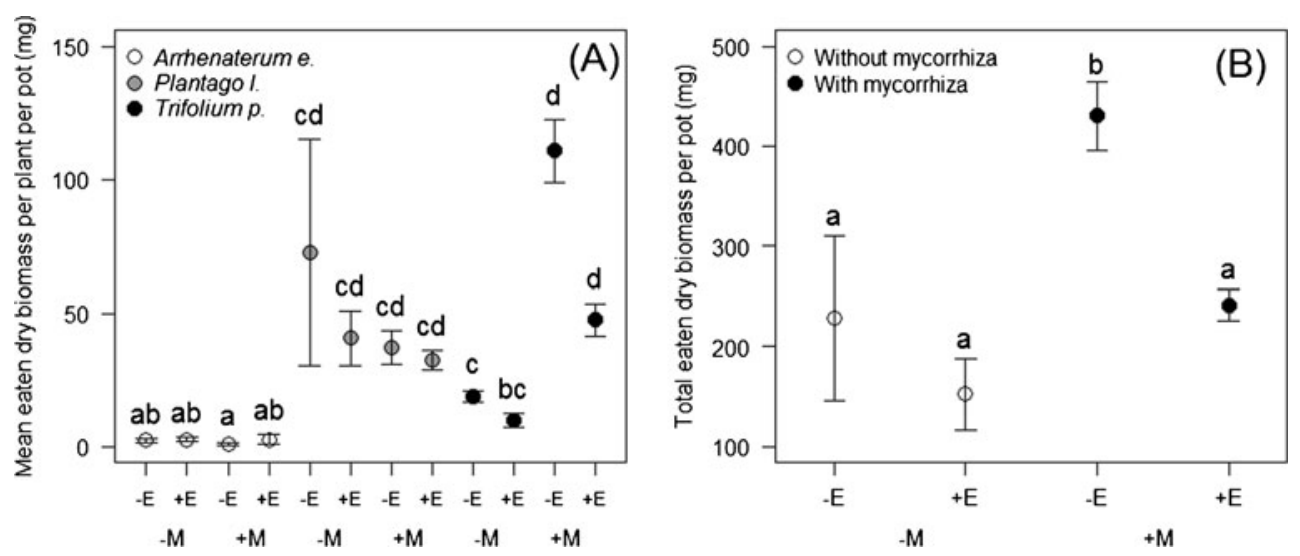
Table 4 ANOVA table for the effects of plant species, AMF and earthworms on absolute (abs., gram of dry mass consumed per pot) and proportional (prop., percent of total consumption per pot) slug herbivory. Only significant interaction terms are listed

\begin{tabular}{|c|c|c|c|c|}
\hline Response variable & Explanatory variable & $D f$ & $F$ value & $P$ value \\
\hline \multirow[t]{2}{*}{ Total herbivory } & AMF & 1 & 8.85 & 0.007 \\
\hline & Earthworms & 1 & 7.36 & 0.013 \\
\hline \multirow[t]{5}{*}{ Herbivory plant spp..$^{-1}$} & Species & 2 & 99.82 & $<\mathbf{0 . 0 0 1}$ \\
\hline & AMF & 1 & 6.87 & 0.011 \\
\hline & Earthworms & 1 & 1.55 & 0.218 \\
\hline & Species $\times$ earthworms & 2 & 13.69 & $<0.001$ \\
\hline & Species $\times$ AMF & 2 & 3.36 & 0.041 \\
\hline \multirow[t]{2}{*}{ Abs. herbivory on A. elatius } & AMF & 1 & 1.46 & 0.241 \\
\hline & Earthworms & 1 & 0.61 & 0.445 \\
\hline \multirow[t]{2}{*}{ Abs. herbivory on $P$. lanceolata } & AMF & 1 & 0.01 & 0.943 \\
\hline & Earthworms & 1 & 0.03 & 0.861 \\
\hline \multirow[t]{2}{*}{ Abs. herbivory on T. pratense } & AMF & 1 & 63.14 & $<\mathbf{0 . 0 0 1}$ \\
\hline & Earthworms & 1 & 14.62 & 0.001 \\
\hline \multirow[t]{2}{*}{ Prop. herbivory on A. elatius } & AMF & 1 & 3.01 & 0.097 \\
\hline & Earthworms & 1 & 1.41 & 0.249 \\
\hline \multirow[t]{2}{*}{ Prop. herbivory on P. lanceolata } & AMF & 1 & 18.60 & $<\mathbf{0 . 0 0 1}$ \\
\hline & Earthworms & 1 & 1.64 & 0.214 \\
\hline \multirow[t]{2}{*}{ Prop. herbivory on $T$. pratense } & AMF & 1 & 37.25 & $<\mathbf{0 . 0 0 1}$ \\
\hline & Earthworms & 1 & 7.12 & 0.014 \\
\hline
\end{tabular}

(more sensitive) individuals of $A$. caliginosa. Hence, some of the reported earthworm effects could also result from nutrient input caused by decomposing worm tissue rather than from actual earthworm activity. In previous experiments with the same substrate type and earthworm species, we documented earthworm activity throughout several months

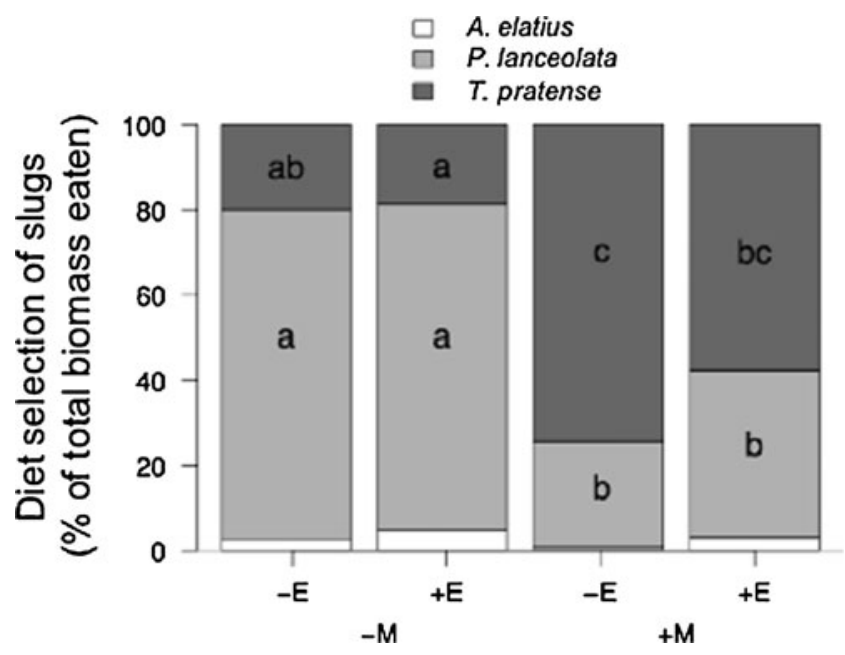

Fig. 3 Diet selection of slugs on A. elatius, P. lanceolata, and T. pratense expressed in percentage of the total leaf biomass consumed in response to earthworms $(-E$, no earthworms; $+E$, earthworms added) or AM fungi ( $-M$, no AMF inoculation; $+M$, with AMF inoculation). Different letters in bar sections denote significant differences within particular species (Tukey's HSD test, $P<0.05$ ). Means, $n=6$
(Zaller et al. 2013b) with earthworm recovering rates of up to $93 \%$ (Zaller et al. 2011c).

Taken collectively, our results show that the feeding habits of slugs in this simple plant community can be affected by both earthworms and AMF. In a previous experiment, we showed that slug herbivory is also affected by the diversity of plant communities with $40 \%$ lower herbivory in communities containing 12 plant species as compared to those containing only three plant species (Zaller et al. 2013a). Effects of earthworms on slug herbivory were greater in low diverse than in high diverse communities (Zaller et al. 2013a).

Whether effects of earthworms and AMF, however, will also be similar under field conditions remains to be investigated. To what extent differential herbivory by an invasive slug species between invasive and native plant species changes species composition of ecosystems has not been studied yet. In any case, these sizeable effects of both earthworms and AMF on these invasive slugs adds further evidence for belowground control of plant community structure via modifying aboveground herbivore behavior. Moreover, these results provide impetus for more attention directed towards belowground-aboveground interactions in order to gain a better insight into processes structuring the diversity and functioning of grassland communities.

Acknowledgments We are grateful to Susanne Sochurek for providing the slugs and to Norbert Schuller and Lina Weissengruber for their help in the laboratory and during the harvest. This work was supported by the Austrian Science Fund (FWF project no. P20171-B16). 
Open Access This article is distributed under the terms of the Creative Commons Attribution License which permits any use, distribution, and reproduction in any medium, provided the original author(s) and the source are credited.

\section{References}

Arnone JAI, Zaller JG, Ziegler C, Zandt H, Körner C (1995) Leaf quality and insect herbivory in model tropical plant communities after longterm exposure to elevated atmospheric $\mathrm{CO}_{2}$. Oecologia 104:72-78

Bennett AE, Alers-Garcia J, Bever JD (2006) Three-way interactions among mutualistic mycorrhizal fungi, plants, and plant enemies: hypothesis and synthesis. Am Nat 167:141-152

Bohlen PJ, Pelletier DM, Groffman PM, Fahey TJ, Fisk MC (2004) Influence of earthworm invasion on redistribution and retention of soil carbon and nitrogen in northern temperate forests. Ecosystems 7:13-27

Bonkowski M, Griffiths BS, Ritz K (2000) Food preferences of earthworms for soil fungi. Pedobiol 44:666-676

Bouché MB (1977) Strategies lombriciennes. In: Lohm U, Persson T (Eds) Soil Organisms as Components of Ecosystems, vol Ecological Bulletins 25, Stockholm. pp 122-133

Bradford MA, Jones TH, Bardgett RD, Black HIJ, Boag B, Bonkowski M, Cook R, Eggers T, Gange AC, Grayston SJ, Kandeler E, McCaig AE, Newington JE, Prosser JI, Setälä H, Staddon PL, Tordoff GM, Tscherko D, Lawton JH (2002) Impacts of soil faunal community composition on model grassland ecosystems. Science 298:615-618

Buschmann H, Keller M, Porret N, Dietz H, Edwards PJ (2005) The effect of slug grazing on vegetation development and plant species diversity in an experimental grassland. Funct Ecol 19:291-298

Cameron DD (2010) Arbuscular mycorrhizal fungi as (agro)ecosystem engineers. Plant Soil 333:1-5

Chevallier AJT, Lieffering M, Carran RA, Newton PCD (2006) Mineral nitrogen cycling through earthworm casts in a grazed pasture under elevated atmospheric $\mathrm{CO}_{2}$. Glob Chang Biol 12:56-60

Christian E, Zicsi A (1999) Ein synoptischer Bestimmungsschlüssel der Regenwürmer Österreichs (Oligochaeta: Lumbricidae). Die Bodenkultur 50:121-131

Cook R, Bailey S, McCrohan C (1996) Slug preferences for winter wheat cultivars and common agricultural weeds. J Appl Ecol 33:866-872

Cowie RH, Dillon RT, Robinson DG, Smith JW (2009) Alien non-marine snails and slugs of priority quarantine importance in the United States: a preliminary risk assessment. Am Malacol Bull 27:113-132

Crawley MJ (1983) Herbivory. The dynamics of animal-plant interactions. Blackwell, Oxford

Curry JP (1994) Grassland invertebrates. Chapman \& Hall, London

Dirzo R (1980) Experimental studies on slug-plant interactions I. The acceptability of thirty plant species to the slug Agriolimax caruanae. J Ecol 68:981-998

Edwards CA, Bohlen PJ (1996) Biology and ecology of earthworms, 3rd edn. Chapman \& Hall, London

Eisenhauer N, König S, Sabais ACW, Renker C, Buscot F, Scheu S (2009) Impacts of earthworms and arbuscular mycorrhizal fungi (Glomus intraradices) on plant performance are not interrelated. Soil Biol Biochem 41:561-567

Fenner M, Hanley ME, Lawrence R (1999) Comparison of seedling and adult palatability in annual and perennial plants. Funct Ecol $13: 546-551$

Frank T (2003) Influence of slug herbivory on the vegetation development in an experimental wildflower strip. Basic Appl Ecol 4:139-147

Frank T, Friedli J (1999) Laboratory food choice trials to explore the potential of common weeds to reduce slug feeding on oilseed rape. Biol Agric Hortic 17:19-29
Gange AC (1993) Translocation of mycorrhizal fungi by earthworms during early succession. Soil Biol Biochem 25:1021-1026

Giovanetti M, Mosse B (1980) An evaluation of techniques for measuring vesicular arbuscular mycorrhizal infection in roots. New Phytol 84:489-500

Gormsen D, Olsson PA, Hedlund K (2004) The influence of collembolans and earthworms on AM fungal mycelium. Appl Soil Ecol 27:211-220

Hanley ME, Fenner M, Edwards PJ (1995a) The effect of seedling age on the likelihood of herbivory by the slug Deroceras reticulatum. Funct Ecol 9:754-759

Hanley ME, Fenner M, Edwards PJ (1995b) An experimental study of the effects of mollusc grazing on seedling recruitment and survival in grassland. J Ecol 83:621-627

Heiner B, Drapela T, Frank T, Zaller JG (2011) Stable isotope ${ }^{15} \mathrm{~N}$ and ${ }^{13} \mathrm{C}$ labelling of different functional groups of earthworms and their casts: a tool for studying trophic links. Pedobiol 54:169-175

Hempel S, Stein C, Unsicker SB, Renker C, Auge H, Weisser WW, Buscot F (2009) Specific bottom-up effects of arbuscular mycorrhizal fungi across a plant-herbivore-parasitoid system. Oecologia 160:267-277

James SW (1991) Soil, nitrogen, phosphorus, and organic matter processing by earthworms in tallgrass prairie. Ecology 72:2101-2109

Jones CG, Lawton JH, Shachak M (1997) Positive and negative effects of organisms as physical ecosystem engineers. Ecology 78:1946-1957

Knop E, Reusser N (2012) Jack-of-all-trades: phenotypic plasticity facilitates the invasion of an alien slug species. Proc Roy Soc B 279:4668-4676

Koricheva J, Gange AC, Jones T (2009) Effects of mycorrhizal fungi on insect herbivores: a meta-analysis. Ecology 90:2088-2097

Lee KE (1985) Earthworms. Their ecology and relationships with soils and land use. Academic, Syndey

Lee KK, Reddy MV, Wani SP, Trimurtulu N (1996) Vesiculararbuscular mycorrhizal fungi in earthworm casts and surrounding soil in relation to soil management of a semi-arid tropical Alfisol. Appl Soil Ecol 3:177-181

Mattson WJ (1980) Herbivory in relation to plant nitrogen content. Ann Rev Ecol Syst 11:119-161

Migge-Kleian S, McLean MA, Maerz JC, Heneghan L (2006) The influence of invasive earthworms on indigenous fauna in ecosystems previously uninhabited by earthworms. Biol Invasions 8:1275-1285

Milleret R, Le Bayon RC, Gobat JM (2009) Root, mycorrhiza and earthworm interactions: their effects on soil structuring processes, plant and soil nutrient concentration and plant biomass. Plant Soil 316:1-12

Ortiz-Ceballos AI, Peña-Cabriales JJ, Fragoso C, Brown CG (2007) Mycorrhizal colonization and nitrogen uptake by maize: combined effect of tropical earthworms and velvetbean mulch. Biol Fertil Soils 44:181-186

Peters HA, Baur B, Bazzaz F, Körner C (2000) Consumption rates and food preferences of slugs in a calcareous grassland under current and future $\mathrm{CO}_{2}$ conditions. Oecologia 125:72-81

Peters HA, Cleland EE, Mooney HA, Field CB (2006) Herbivore control of annual grassland composition in current and future environments. Ecol Lett 9:86-94

Putz B, Drapela T, Wanek W, Schmidt O, Frank T, Zaller JG (2011) A simple method for in-situ-labelling with ${ }^{15} \mathrm{~N}$ and ${ }^{13} \mathrm{C}$ of grassland plant species by foliar brushing. Methods Ecol Evol 2:326-332

R Development Core Team R (2008) R: A language and environment for statistical computing. R Foundation for Statistical Computing, Vienna, Austria

Reddell P, Spain AV (1991) Earthworms as vectors of viable propagules of mycorrhizal fungi. Soil Biol Biochem 23:767-774

Sanchez-de Leon Y, Johnson-Maynard J (2009) Dominance of an invasive earthworm in native and non-native grassland ecosystems. Biol Invasions 11:1393-1401

Scheu S (2003) Effects of earthworms on plant growth: patterns and perspectives. Pedobiol 47:846-856 
Smith SE, Read DJ (2008) Mycorrhizal symbiosis, 3rd edn. Academic, London

South A (1992) Terrestrial slugs: biology, ecology, control. Chapman \& Hall, London

Thompson L, Thomas CD, Radley JMA, Williamson S, Lawton JH (1993) The effect of earthworms and snails in a simple plant community. Oecologia 95:171-178

Tuffen F, Eason WR, Scullion J (2002) The effect of earthworms and arbuscular mycorrhizal fungi on growth of and P-32 transfer between Allium porrum plants. Soil Biol Biochem 34:1027-1036

United Nations Environment Programme (2006) Millennium ecosystem assessment. In: Cleveland CJ (Ed) Encyclopedia of Earth. Environmental Information Coalition, National Council for Science and the Environment, Washington, DC, USA,

Vierheilig H, Coughlan AP, Wyss U, Piche Y (1998) Ink and vinegar, a simple staining technique for arbuscular-mycorrhizal fungi. Appl Environ Microbiol 64:5004-5007

Wang B, Qiu Y-L (2006) Phylogenetic distribution and evolution of mycorrhizas in land plants. Mycorrhiza 16:299-363

Wurst S (2010) Effects of earthworms on above- and belowground herbivores. Appl Soil Ecol 45:123-130

Wurst S, Dugass-Gobena D, Scheu S (2004a) Earthworms and litter distribution affect plant defensive chemistry. J Chem Ecol 30:691702

Wurst S, Dugassa-Gobena D, Langel R, Bonkowski M, Scheu S (2004b) Combined effects of earthworms and vesicular-arbuscular mycorrhizas on plant and aphid performance. New Phytol 163:169-176

Wurst S, Forstreuter M (2010) Colonization of Tanacetum vulgare by aphids is reduced by earthworms. Entomol Exp Appl 137:8692

Wurst S, Jones TH (2003) Indirect effects of earthworms (Aporrectodea caliginosa) on an above-ground tritrophic interaction. Pedobiol 47:91-97
Wurst S, Langel R, Reineking A, Bonkowski M, Scheu S (2003) Effects of earthworms and organic litter distribution on plant performance and aphid reproduction. Oecologia 137:90-96

Zaller JG, Arnone JA (1997) Activity of surface-casting earthworms in a calcareous grassland under elevated atmospheric $\mathrm{CO}_{2}$. Oecologia 111:249-254

Zaller JG, Frank T, Drapela T (2011a) Soil sand content can alter effects of different taxa of mycorrhizal fungi on plant biomass production of grassland species. Eur J Soil Biol 47:175-181

Zaller JG, Heigl F, Grabmaier A, Lichtenegger C, Piller K, Allabashi R, Frank T, Drapela T (2011b) Earthworm-mycorrhiza interactions can affect the diversity, structure and functioning of establishing model grassland communities. PLoS One 6:e29293

Zaller JG, Parth M, Szunyogh I, Semmelrock I, Sochurek S, Pinheiro M, Frank T, Drapela T (2013a) Herbivory of an invasive slug is affected by earthworms and the composition of plant communities. BMC Ecol 13:20

Zaller JG, Saccani F, Frank T (2011c) Effects of earthworms and mycorrhizal fungi on the growth of the medicinal herb Calendula officinalis (Asteraceae). Plant Soil Environ 57:499-504

Zaller JG, Searles PS, Rousseaux MC, Flint SD, Caldwell MM, Sala O, Ballaré CL, Scopel AL (2003) Solar ultraviolet-B radiation can affect slug feeding preference for some plant species native to a fen ecosystem in Tierra del Fuego, Argentina. Plant Ecol 169:43-51

Zaller JG, Wechselberger KF, Gorfer M, Hann P, Frank T, Wanek W, Drapela T (2013b) Subsurface earthworm casts can be important soil microsites specifically influencing the growth of grassland plants. Biol Fertil Soils. doi:10.1007/s00374-00013-00808-00374

Zarea MJ, Ghalavand A, Goltapeh EM, Rejali F, Zamaniyan M (2009) Effects of mixed cropping, earthworms (Pheretima sp.), and arbuscular mycorrhizal fungi (Glomus mosseae) on plant yield, mycorrhizal colonization rate, soil microbial biomass, and nitrogenase activity of free-living rhizosphere bacteria. Pedobiol 52:223-235 